\title{
Teeth complexity, hypsodonty and body mass in Santacrucian (Early Miocene) notoungulates (Mammalia)
}

\author{
Guillermo H. Cassini ${ }^{1,2,7}$, Santiago Hernández Del Pino ${ }^{3,7}$, \\ Nahuel A. Muñoz ${ }^{4,7}$, M. V. Walter G. Acosta ${ }^{5}$, Mercedes Fernández ${ }^{2,6,7}$, \\ M. Susana Bargo ${ }^{4,8}$ and Sergio F. Vizcaíno ${ }^{4,7}$
}

${ }^{1}$ División Mastozoología, Museo Argentino de Ciencias Naturales "Bernardino Rivadavia”, Ciudad Autónoma de Buenos Aires, Argentina.

Email: gcassini@macn.gov.ar

${ }^{2}$ Departamento de Ciencias Básicas, Universidad Nacional de Luján, Luján, Buenos Aires, Argentina.

Email: mechi_985@hotmail.com

${ }^{3}$ Paleontología, Instituto de Nivología, Glaciología y Ciencias Ambientales, Centro Científico Tecnológico -

CONICET Mendoza, Mendoza, Argentina.

Email: shdelpino@mendoza-conicet.gob.ar

${ }^{4}$ División Paleontología Vertebrados, Museo de La Plata, Unidades de Investigación Anexo Museo, FCNyM-UNLP, 60 y 122, 1900 La Plata, Argentina.

Email: nahuelmunoz@fcnym.unlp.edu.ar; msbargo@fcnym.unlp.edu.ar; vizcaino@fcnym.unlp.edu.ar

${ }^{5}$ Cátedra de Semiología, Facultad de Ciencias Veterinarias, Universidad Nacional de La Plata, Calle 60 y 118 s/n, La Plata, Argentina.

Email: waltergustavoacosta@email.com

${ }^{6}$ División Paleontología de Vertebrados, Museo Argentino de Ciencias Naturales "Bernardino Rivadavia", Ciudad Autónoma de Buenos Aires, Argentina.

${ }^{7}$ CONICET. Consejo Nacional de Investigaciones Científicas y Técnicas.

${ }^{8}$ CIC. Comisión de Investigaciones Científicas de la provincia de Buenos Aires.

\begin{abstract}
Notoungulates, native South American fossil mammals, have been recently objective of several palaeoecological studies. Ecomorphology and biomechanics of the masticatory apparatus, together with micro and mesowear analyses on tooth enamel, were applied in order to understand their palaeobiology. In particular, the relationship between some dental traits (hypsodonty, occlusal surface area and complexity) and body mass is still poorly understood. These features were measured by means of the hypsodonty index (HI), occlusal surface area (OSA) and tooth area (OTA), enamel crest complexity (ECC) and length (OEL). The relationships between these indices were evaluated in five pan-contemporaneous Santacrucian Notoungulata genera from Patagonia: Adinotherium and Nesodon (Toxodontia), Interatherium, Protypotherium and Hegetotherium (Typotheria). While OSA, OTA and OEL were size dependent and strongly correlated, HI and ECC were size independent. All notoungulates analysed have very hypsodont teeth, indicating high rates of tooth wear in response to an increase of abrasives consumed with the food; their tooth occlusal area and complexity could be related to chewing efforts associated with the toughness of the plants consumed. HI, OSA and ECC were considered useful for palaeoecological reconstructions, but the results presented here show that these three features are integrated as a complex, so should not be evaluated separately.
\end{abstract}

KEY WORDS: Fractal dimension, hypsodonty index, occlusal surface area, palaeobiology

Several extinct South American native ungulate lineages evolved within the geographical context of isolation during most of the Cenozoic. Amongst them, Notoungulata constitutes the most abundant and diverse clade, both taxonomically and morphologically (Simpson 1936; Patterson \& Pascual 1972; Bond 1986; Cifelli 1993; Croft 1999). Following Billet (2010), the clade comprises two main monophyletic groups, Toxodontia and Typotheria, plus some basal notoungulate families. During the Santacrucian Age (Santa Cruz Formation, Early Miocene of Patagonia), the notoungulates were very diverse (Fig. 1), with three genera of Toxodontia (Nesodon and Adinotherium (Toxodontidae, Nesodontinae) and Homalodotherium (Homalodotheriidae)) and four genera of Typotheria (Interatherium and Protypotherium (Interatheriidae) and Hegetotherium and Pachyrukhos (Hegetotheriidae)). Cassini et al. (2012a) provided an extensive description of the diversity of all Santacrucian native ungulates in a bounded geographic and stratigraphic context. Their remains are particularly interesting for palaeobiological studies, due to their richness and the availability of specimens with fine quality preservation. In the past decade, there have been several studies trying to shed light on the palaeobiology of South American ungulates. They dealt with body mass estimations (Croft 2001; Scarano et al. 2011; Cassini et al. 2012b; Elissamburu 2012); ecomorphological characterisations (Elissamburu 2004, 2010; Croft \& Anderson 2008; Cassini et al. 2011, 2012a; Cassini 2013; Giannini \& García-López 
(A)

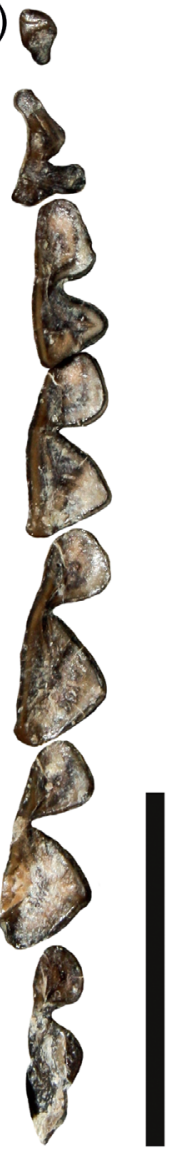

(B)
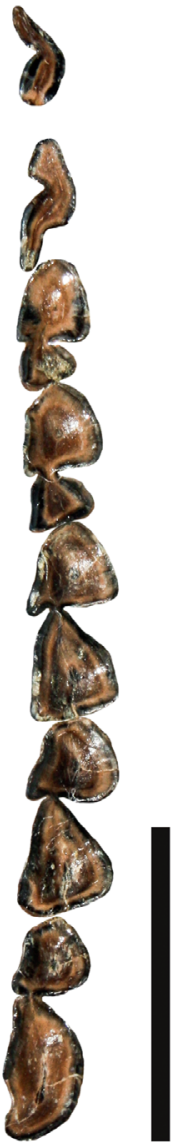

(C)

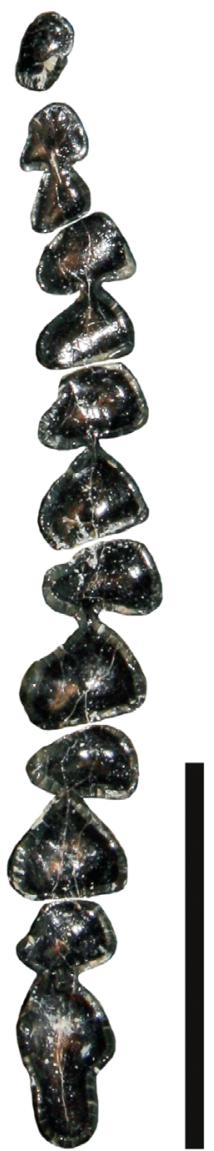

(D)

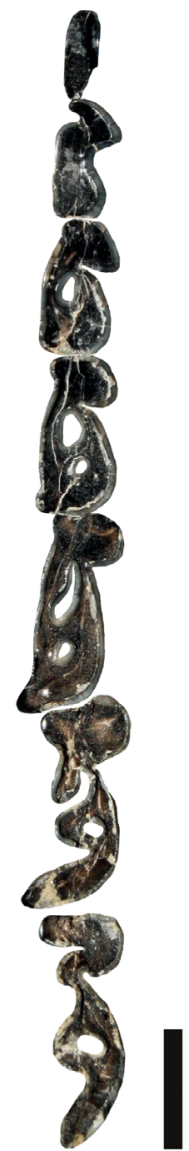

$(\mathrm{E})$

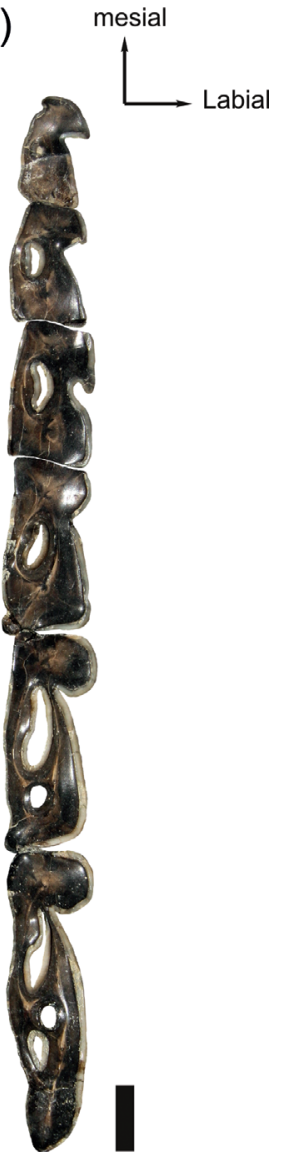

Figure 1 Santacrucian notoungulate, right side lower tooth rows (except where indicated): (A) Hegetotherium mirabile, MPM-PV 3481; (B) Protypotherium praerutilum, MPM-PV 3530 (left side reversed); (C) Interatherium robustum MPM-PV 3528; (D) Adinotherium ovinum, MPM-PV 3667; (E) Nesodon imbricatus, MPM-PV 3659. Scale bars $=10 \mathrm{~mm}$

2014); teeth wear and durability (Townsend \& Croft 2008; Billet et al. 2009; Reguero et al. 2010); biomechanical performance of the masticatory apparatus (Cassini \& Vizcaíno 2012); and digestion physiology (Scarano et al. 2011; Cassini et al. 2012a).

Much research has focused on the relationship between mammalian dental morphology (i.e., size, shape and wear) and habitat and trophic characterisations (Ungar \& Williamson 2000). In herbivorous forms particularly, this was achieved by the study of tooth crown height (hypsodonty), tooth occlusal surface area and complexity, and body mass.

The height of the tooth crown is one of the morphological features that has been of most interest for palaeobiologists, and the South American fauna is the oldest one in the world dominated by hypsodont herbivores (Flynn \& Wyss 1998; Flynn et al. 2003). Hypsodonty has been frequently considered as indicative of grass consumption in ungulates, and correlated with the spread of grass land habitats (see Patterson \& Pascual 1968 and Madden 2015 for South America; and Janis 1995, MacFadden 2000, Strömberg 2006 and Strömberg et al. 2007 for central North America and western Eurasia). Van Valen (1960) provided the first quantitative approach to these relationships, defining a hypsodonty index (HI); but it was not until the late 1980s that a comparative study by Janis (1988) tested the relation to grass consumption in living ungulates, hyraxes and the African elephant. Although she found a positive correlation between HI and percentage of grass in diet, further research (Janis 1995) led this author to conclude that HI better indicates open-habitat environmental preference rather than grass consumption in extinct ungulates. Williams
\& Kay (2001) found that tooth crown height in rodents and ungulates was positively correlated with the proportion of monocots (primarily grass) in the diet, and negatively correlated with foraging height preferences. Mendoza \& Palmqvist (2008) indicated that, in extant ungulates, there is no direct relationship between the degree of hypsodonty and the amount of grass consumed, except for the correspondence between grazing and dwelling in open habitats. The significance of hypsodonty in this context is that it prolongs the life of teeth in herbivores which deal with abundant abrasives, such as silica-rich grasses and wind-blown dust, in these open, arid habitats.

The appearance of a large number of hypsodont notoungulates occurred sometime between $36 \mathrm{Ma}$ and $32 \mathrm{Ma}$ (Late Eocene-Early Oligocene) (Kay et al. 1999). Hypsodonty developed in six notoungulate families - notohippids, toxodontids, interatheriids, mesotheriids, archaeohyracids and hegetotheriids - and may correspond to three or more independent acquisitions (Croft \& Weinstein 2008). Strömberg et al. (2013) found that the earliest grass-dominated habitat was established in Patagonia sometime after $18.5 \mathrm{Ma}$, and not at $40 \mathrm{Ma}$ as proposed by Zucol et al. (2010). Consequently, Strömberg et al. (2013) rejected the hypothesis that the early evolution of hypsodonty in southern South America was driven by the spread of grasslands, and concluded that grass dominance and openness of vegetation are not necessary pre-conditions for favouring high-crowned dentition. However, they stated that it is still likely that environmental abrasiveness was the ultimate trigger for the evolution of hypsodonty. 
Cassini et al. (2011) generated inferences about habitat and feeding preferences in an assemblage of Santacrucian notoungulates (Early Miocene, 16-17 Ma), using classic morphometrics and novel computer techniques of knowledge discovery. Although these authors warn about the shape differences amongst lineages, their results are mostly driven by the hypsodonty index. The results suggest that all Santacrucian notoungulates have morphologies characteristic of 'open habitat' extant ungulates, in agreement with classical ideas (Scott 1937; Patterson \& Pascual 1968; Tauber 1996; Madden 1997). More recently, using 3D morphometrics, Cassini (2013) found parallel mandibular shape characteristics related to HI between those herbivorous forms with incisor-like canines and those with well-developed canines or incisors. Extant brachyodont ungulates from closed habitats show a more elongated and narrower mandibular symphysis, with a lower mandibular corpus, than that of hypsodont, open habitat species. Therefore, in addition to extending the tooth life functionality, a high crown seems to be related to mandibular shape.

Several authors have found that amongst ungulates and kangaroos, grazers have a cheek teeth occlusal surface area (OSA; Pérez-Barbería \& Gordon 1998a) larger than that of browsers, using as a proxy a simple product of tooth length multiplied by width (Janis 1990, 1995; Janis \& Constable 1993; Pérez-Barbería \& Gordon 2001; Mendoza et al. 2002). In addition, Janis (1988) stated that perissodactyls (monogastric forms) have longer molarised premolar rows than artiodactyls (ruminant). Later, Janis \& Constable (1993) and Janis (1995) proposed that these differences are related to different alimentary strategies in relation to the physiology of digestion. For example, horses spend more time chewing, and also chew more than cows (ruminants) when they eat high-fibre-content food. In addition, OSA was assumed to be directly correlated with the quantity of food trapped between tooth rows and, therefore, a large OSA will also increase the amount of food fragments cut or ground per chewing cycle (Pérez-Barbería \& Gordon 1998b and references therein).

Following these ideas, Vizcaíno et al. $(2006,2011)$ refined the methodology to measure the occlusal surface area, taking into account the tooth infolding instead of using a rectangular box as a proxy. They evaluated this dental feature in a reference sample of herbivorous mammals and the extinct hypsodont xenarthrans. These authors agreed with Janis' statements mentioned above (Janis \& Constable 1993; Janis 1995) and concluded that OSA is strongly correlated with body mass (but is also a useful measure of the capacity to process food in the oral cavity) and, indirectly, is correlated with some aspects of feeding physiology and metabolism. Later, Cassini et al. (2012a) applied the same approach to the Santacrucian ungulates and proposed that Litopterna and Notoungulata parallel the relationships between the perissodactyls and artiodactyls (i.e., litopterns have a relatively larger OSA than that of notoungulates and, consequently, more efficient intraoral food processing and perhaps not as good digestive capabilities). Amongst Notoungulata, Toxodontia tend to have greater OSA than that predicted for an herbivorous mammal of the same body mass, whilst Typotheria tend to have lower values. Recently, applying the same method as Vizcaíno et al. (2006) and Cassini et al. (2012a), Famoso et al. (2013) evaluated each tooth separately (the "true occlusal tooth area") in a broader extant ungulate sample and in a phylogenetic context, and arrived at similar conclusions.

More recently, there has been some interest in the study of enamel crest length and complexity, its relation with the HI, and its value for the inference of diet and feeding behaviour in extinct ungulates. Using fractal dimension, Candela et al. (2013) quantified the enamel crest complexity (ECC) of a gigantic hypsodont dynomid rodent to evaluate chewing effi- ciency. Famoso et al. (2013) measured the occlusal enamel length (OEL) in ungulate teeth, finding that it was constrained by the occlusal tooth area and diet. They also proposed an occlusal enamel index (OEI), defined as the ratio between enamel length and the square root of occlusal area, to evaluate the component of enamel length determined by abrasiveness of ingested material reducing the effect of body mass.

Some authors have attempted to evaluate how tooth crown height (HI), occlusal surface area (OSA) and enamel crest complexity (ECC) relate to each other. For example, Vizcaíno et al. (2006) analysed xenarthran cingulates (pampatheres vs. glyptodonts), and suggested that the less complex tooth lobation, but larger OSA, in pampatheres could be a consequence of a balance in which a reduction in one feature is compensated by an increase in the other. Reguero et al. (2010) suggested that in typotheres, the occlusal design plays an important role in the relationship between hypsodonty and body mass (BM), and that these three factors form a complex of characters. Candela et al. (2013) proposed that chewing efficiency of the dynomid rodent could be functionally more related to ECC than hypsodonty. These authors remarked that the relationship of ECC and hypsodonty with factors such as teeth effectiveness, food physical attributes and the ingestion of soil particles, remains elusive. Famoso et al. (2013) found that OEL alone was useless for determining feeding strategies. They also proposed that a further examination of the fractal dimension would remove the effects of body size from studies of tooth complexity. Later, Famoso et al. (2016) tested the value of OEI, HI and phylogeny combined, to characterise feeding behaviour in extant ungulates. They found that although diets of extant ungulates are significantly related to each of these traits independently, there is no clear evolutionary connection between $\mathrm{HI}$ and OEI.

The goal of this work is to further explore the relationships between HI, OSA, ECC (as a fractal dimension) and BM, by studying a set of specimens of South American native notoungulates that lived in Patagonia at the same time as the earliest grass-dominated habitats were already established.

\section{Materials and methods}

\subsection{Specimens}

The following samples, housed at the Museo Regional Provincial Padre M. J. Molina, Paleontología Vertebrados (MPMPV), Río Gallegos, Argentina, represent the notoungulates recorded in a constrained set of localities in the lower part of the Santa Cruz Formation in the Atlantic coast of the Santa Cruz Province (Argentina). In particular, we analysed the taxa recorded by Kay et al. (2012) in the Fossiliferous Levels 1-7 of Tauber (1997); excluding Homalodotherium, for which there are no mandibles recovered from those levels. These taxa represent a narrow temporal window $(\sim 17.4-17.5 \mathrm{Ma}$; Fleagle et al. 2012; Perkins et al. 2012), which allows palaeoecological integration. See Vizcaíno et al. (2012) for a detailed description of the localities mentioned.

1.1.1. Toxodontia. Adinotherium ovinum: MPM-PV 3660, mandible. Locality: Puesto Estancia La Costa (= Corriguen Aike); MPM-PV 3666, cranium and mandible (sub-adult specimen; see Cassini et al. 2012c). Locality: Campo Barranca; MPM-PV 3667, complete cranium and mandible, ulna. Locality: Campo Barranca; MPM-PV 3668, complete cranium and mandible. Locality: Puesto Estancia La Costa (= Corriguen Aike).

Nesodon imbricatus: MPM-PV 3446, mandible (sub-adult specimen; see Cassini et al. 2012c). Locality: Campo Barranca; MPM-PV 3659, complete cranium and mandible; atlas. Locality: Puesto Estancia La Costa (= Corriguen Aike). 


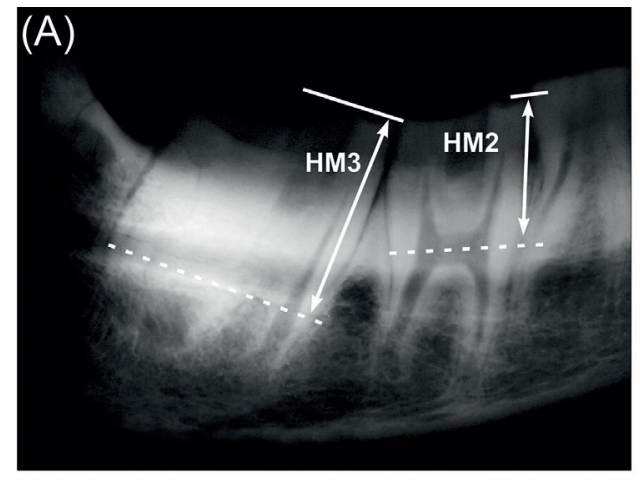

(B)

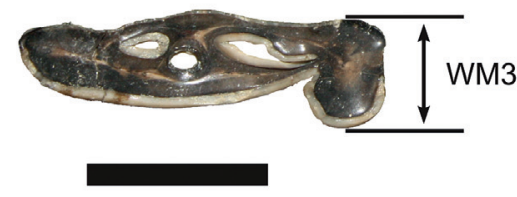

(C)

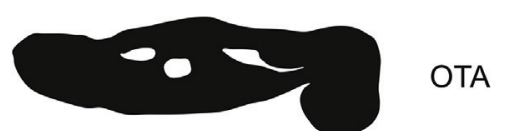

(D)
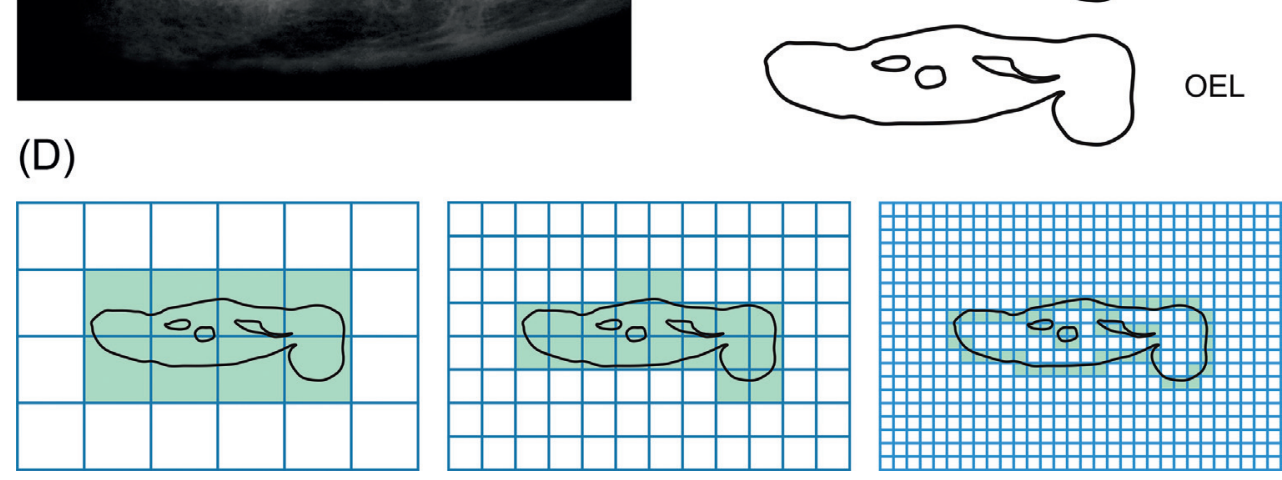

Figure 2 Tooth measurements exemplified in Nesodon imbricatus: (A) RX- Radiography of the right mandible, showing the molar height measurements; (B) occlusal view of $\mathrm{m} 3$ with the third molar width length (WM3), following Janis (1990); (C) tiff images for measuring the occlusal tooth area (OTA) and occlusal enamel length (OEL), following Famoso et al. (2013); (D) box counting method for obtaining the Minkowski-Bouligand fractal dimension, following Candela et al. (2013). Scale bar $=22.5 \mathrm{~mm}$.

1.1.2. Typotheria. Interatheriidae. Protypotherium australe: MPM-PV 3531, mandible. Locality: Campo Barranca.

Protypotherium attenuatum: MPM-PV 3470, cranium and mandible. Locality: Puesto Estancia La Costa (= Corriguen Aike); MPM-PV 3482, mandibular rami with p3-m3. Locality: Puesto Estancia La Costa (= Corriguen Aike); MPM-PV 3661, mandible. Locality: Campo Barranca.

Protypotherium praerutilum: MPM-PV 3530, mandible vertebrae, femur and fibulae. Locality: Puesto Estancia La Costa (= Corriguen Aike).

Interatherium robustum: MPM-PV 3469, cranium and mandible, vertebrae and ulna. Locality: Estancia La Costa; MPM-PV 3471, cranium and mandible and humerus. Locality: Anfiteatro; MPM-PV 3479, complete mandible. Locality: Estancia La Costa; MPM-PV 3480, mandible. Locality: Puesto Estancia La Costa (= Corriguen Aike); MPM-PV 3528, mandible. Locality: Anfiteatro.

Hegetotheriidae. Hegetotherium mirabile: MPM-PV 3481, mandible (sub-adult specimen). Locality: Puesto Estancia La Costa (= Corriguen Aike).

\subsection{Tooth measurements}

X-ray images of mandibles were taken from the lateral norm. The occlusal surfaces of the mandibular cheek teeth, including molar (m) and premolar (p) rows, and the X-ray images, were photographed with a ten-megapixel digital camera. The variables defined below were measured in millimetres on the digital photographs, using the public domain NIH image program ImageJ (Rasband 1997-2007).

1.2.1. Hypsodonty index (HI). The HI of notoungulates was obtained following Janis (1988): the crown height ratio of $\mathrm{m} 3$ was calculated as the crown height (taken from X-ray images) divided by the labio-lingual width of the tooth. In addition, we measured the crown height of the three molar pieces (Fig. 2A, B).

1.2.2. Occlusal surface area (OSA). Occlusal surface area is defined, as in Vizcaíno et al. $(2006 ; 2011)$, as the functional cheek tooth occlusal surface area (without p1, see results), taking into consideration the infolding contour of the tooth (Fig. 2C). We evaluated OSA as the two-dimensional projection of a three-dimensional structure, using digital photos of the occlusal surfaces of the lower cheek tooth (instead of the upper as in Vizcaíno et al. 2006 and Cassini et al. 2012a). In addition, we calculated the occlusal tooth area (OTA) in each piece, following Famoso et al. (2013), who applied the same method as Vizcaíno et al. (2006) and Cassini et al. (2012a), but to each tooth separately.

1.2.3. Tooth complexity. We followed two procedures to quantify tooth complexity, by means of occlusal enamel length (OEL) as the perimeter of enamel infolding of the tooth (Famoso et al. 2013; Fig. 2C), and the enamel crests complexity (ECC) as the fractal dimension (D) of enamel infolding (Candela et al. 2013). These authors use D, defined as the identification and quantification of self-similarity in invariant scale, to evaluate how an object (enamel edges) fills the available space (tooth occlusal surface area), as in Stone \& Telford (2005).

Following Candela et al. (2013), fractal dimension was calculated as a mean of twelve repetitions using random box positions by box counting method (Fig. 2D), implemented in FracLac 2.5 Release 1d-ImageJ Plugin, using four pixels as a minor box unit, and a series of a power formula of base two with 1028 pixels as a major box unit. In addition, six Tiff images of an Euclidean line $(\mathrm{D}=1)$ and five theoretical known fractals of dimensions nearest one (Gosper's isle edge, $\mathrm{D}=$ 1.0689; Koch curve, $\mathrm{D}=1.2619$ ), middle range (Viscek, $\mathrm{D}=$ 1.4649; Sierpinski triangle, $\mathrm{D}=1.585$ ) and nearest two (Sierpinski carpet, $\mathrm{D}=1.18928$ ) were included in the same batch process to assess the accuracy and correct for biases on the $\mathrm{D}$ calculated.

\subsection{Body mass (BM)}

Body masses of Santacrucian notoungulate specimens were estimated using cranio-dental interspecific allometric equations of extant ungulates (Artiodactyla and Perissodactyla) proposed by Janis (1990). We selected the equation derived from the lower molar row length (LMRL) for "all ungulates", 
based on the value of the percentage of variance explained $\left(\mathrm{R}^{2}\right)$, the percent predictive error $(\% \mathrm{PE})$, and availability of the variable involved in the equation amongst the fossil specimens.

\subsection{Analyses}

For the purposes of this study, only specimens from which all variables could be taken were included in the analyses. The genus was chosen as the working taxonomic level, rather than species, because they are more stable taxonomic units accepted by most palaeontologists (see Cassini et al. 2012a and references therein). Descriptive statistics were calculated using R software. Variable normality was analysed with a Shapiro-Wilk test (Shapiro \& Wilk 1965). Differences between teeth heights were contrasted by means of non-parametrical Wilcoxon signed rank test. Following Cassini et al. (2012b), we assessed the extent and significance of the association between variables via Spearman rank non-parametric correlations. This procedure tests how monotonically the variables are related, even if their relationship is not linear (Zar 1999); therefore, we used the original non-transformed data.

The OSA grows at square rate, whereas BM does so at cube rates, because they are measurements of surface vs. volume. So, the two variables were log (base 10) transformed, converting the relationship of these variables from a power formula $\left(\mathrm{OSA}=\mathrm{aBM}^{\mathrm{b}}\right)$ to a straight line: $\log (\mathrm{OSA})=\log (\mathrm{a})+\mathrm{b}$ $\log (\mathrm{BM})$. The allometric relationship (scaling) of OSA with BM was assessed by the standardised major axis (SMA; reduced major axis) method, as this is more appropriate for dealing with allometric approaches (see Warton et al. 2006). Deviations from isometry were assessed by comparing the allometric coefficient with the value of 0.67 (2/3) expected under geometric similarity by means of $F$-tests (Warton \& Weber 2002).

Theoretical and mean values of known fractals were compared by two-tailed Student's t-test. Differences on means of teeth and individual crest D were analysed by ANOVA procedures and post-hoc Tukey's t-test.

Two principal component (PC) analyses were made, the first on $\log$ (base 10) transformed Euclidean variables (lengths and surfaces). The second was made on size independent variables, HI and ECC; given the different nature of the variables, the correlation matrix was used.

\section{Results}

\subsection{Lower tooth morphology}

All Santacrucian notoungulates studied here have complete dentition, with the general dental formula for placental mammals (I3/3 C1/1 P4/4 M3/3). In the lower dentition of typotheres, the incisors are procumbent, inserted following the direction of the anterior face of the symphysis, and the root heights are about the same as those of the crown. The i1 and i2 have a cylindrical section shape, except in Hegetotherium, in which they are bilaterally compressed. In Protypotherium, the i3, canine and $\mathrm{p} 1$ are bilaterally compressed and similar in size; whilst in Hegetotherium and Interatherium, the i3, canine and p1 are incisor-like and reduced in size. Although the crown morphology of cheek teeth is quite different between the three taxa, all show $\mathrm{p} 2$ to $\mathrm{m} 2$ as bilobated and $\mathrm{m} 3$ tending to be trilobated. In Hegetotherium (Fig. 1A), p3 and p4 are molarised and bear a well-developed labial sulcus, differentiating trigonid from talonid; tooth size increases from $\mathrm{p} 3$ to $\mathrm{m} 3$, the trigonid remains subequal and rounded, and the talonid increases in size and is triangular in section. In Protypotherium (Fig. 1B), there are two opposite sulci on the cheek teeth, with the labial sulcus deeper than the lingual groove, giving it an asymmetrical occlusal appearance. In addition, the talonid is smaller than the trigonid in the premolars, whilst the opposite is observed in the molars. In Interatherium, both sulci are very deep along the tooth row, and the labial sulcus is the most excavated in the molars (Fig. 1C). In the three genera of typotheres, the talonid of p2 has a smaller surface than the trigonid, and this relationship is reversed towards the molars, resulting in an $\mathrm{m} 3$ with trilobated aspect.

Besides the differences in crown morphology, in all studied typotheres $\mathrm{p} 3$ to $\mathrm{m} 3$ are rootless at advanced ontogenetic stages and develop immediately above the mandibular canal, being all of approximately the same height (Fig. 3). They are almost parallel, except for the $\mathrm{m} 3$, which is anteriorly directed, leaving more bone near the growing line between two adjacent teeth. The pulpar cavity never extends up from the alveolar margin. Unlike the other notoungulates, Interatherium has a well-developed process of the mandibular corpus, below the mandibular canal, formed by trabecular bone (Fig. 3A).

In both nesodontines, Adinotherium and Nesodon, the incisors are inserted in the same direction as the anterior face of the symphysis, with the crown mesially oriented. The third incisor became hypertrophied during ontogeny, with its root reaching the p3 level. It has a half-round cane transverse section, and wears against $\mathrm{I} 2$. The canine and $\mathrm{p} 1$ are simple and reduced in size. In the remaining cheek teeth, the trigonids have almost the same dimensions, while the talonids increase in size from p2 to $\mathrm{m} 3$ (Fig. 1D-E). The trigonid of unworn molars has a lingually-oriented pike shape (better marked in Adinotherium than in Nesodon), due to the orientation of the mesiolingual paraconid, distolingual metaconid, and labial protoconid (Fig. 1D). The trigonid is separated from the talonid by labial and lingual sulci. In advanced wear stages, the metaconid and entoconid folds lingually fuse, forming a trigonid-talonid fossetid, whilst the trigonid acquires a rounded quadrangular shape. In addition, the entolophid fossetid remains invariable with advanced wear (Fig. 1E). Therefore, the crown morphology became altered by wear and the complexity of the occlusal morphology increases from premolar to molars due to the presence of different dental structures, such as folds and fossetids. Unlike in typotheres, $\mathrm{m} 1$ and $\mathrm{m} 2$ eventually develop roots in advanced ontogenetic stages, whilst $\mathrm{m} 3$ remains rootless (Fig. 4A). However, by the time the third molar is developed but not yet erupted, the roots of $\mathrm{m} 1$ and $\mathrm{m} 2$ remain open, with the tooth crown occupying all the mandibular ramus height (Fig. 4B).

\subsection{Tooth measurements}

Amongst typotheres, crown heights of the two first molars are quite similar (Table 1) and there is no significant differences after a paired Wilcoxon signed rank test (Interatherium: $V=9$, $p$-value $=0.8125$; Protypotherium: $V=8, p$-value $=0.375)$. In Hegetotherium, the third molar tends to be higher than the other molars, whilst in interatheriids the opposite trend is observed (Table 1). In both toxodontids, the crown height increases from $\mathrm{m} 1$ to $\mathrm{m} 3$. Both Interatherium and Nesodon show the lowest HI ( $\sim 3.3)$; whereas Protypotherium and Adinotherium have intermediate HI ( $\sim 4$ and $\sim 4.7$ respectively) and Hegetotherium is the most hypsodont taxon ( $\mathrm{HI} \sim 7.8)$. The hypsodonty index (Table 1) is not correlated with body mass $\left(n=15, r_{S}=\right.$ 0.186$, $p$-value $=0.5067)$.

The occlusal tooth area (OTA) shows a general pattern of progressively increasing values from $\mathrm{p} 1$ to $\mathrm{m} 1$ (Table 1), the highest increase being between $\mathrm{p} 4$ and $\mathrm{m} 1$ in Adinotherium, Nesodon and Protypotherium. Within molars, there are three cases: a progressive increase from $\mathrm{m} 1$ to $\mathrm{m} 3$ in Nesodon; similar values between $\mathrm{m} 1$ and $\mathrm{m} 2$ but lower in $\mathrm{m} 3$ in Adinotherium and Hegetotherium; and similar values between $\mathrm{m} 1$ and $\mathrm{m} 2$ but 


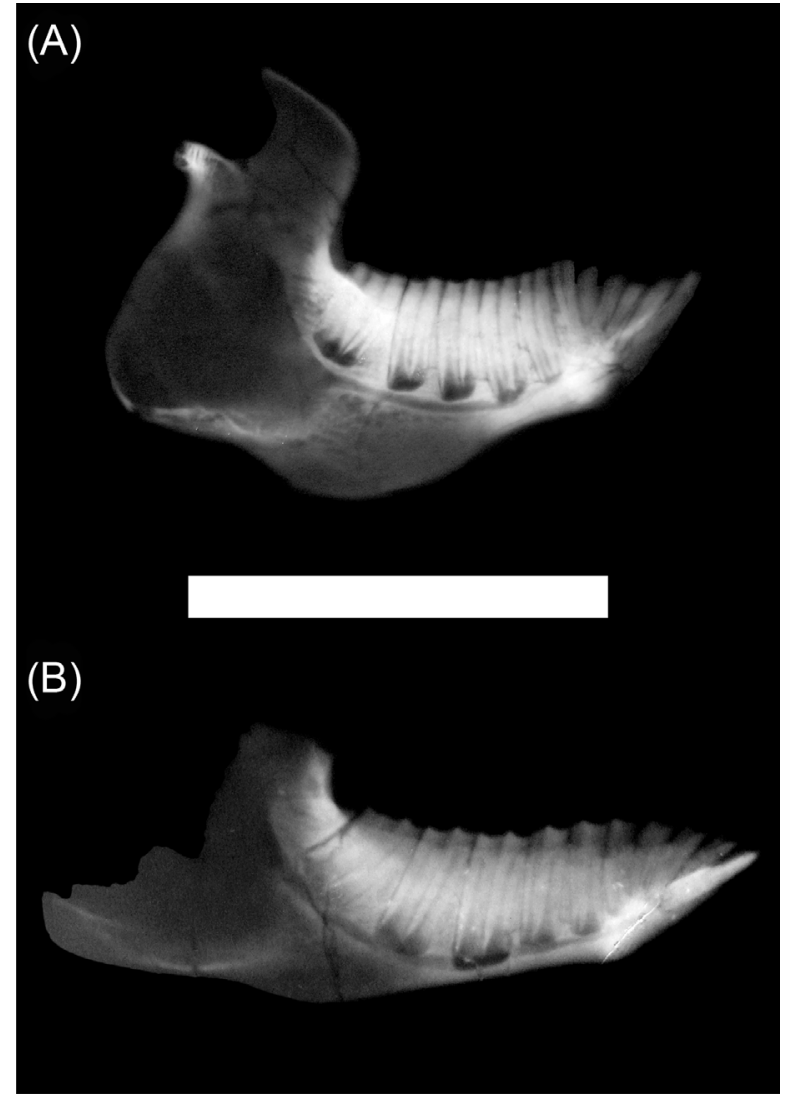

Figure 3 X-ray images of typothere, left hemi-mandibles: (A) Interatherium robustum, MPM-PV 3471; (B) Protypotherium praerutilum, MPM-PV 3530. Scale bar $=50 \mathrm{~mm}$

higher in $\mathrm{m} 3$ in Interatherium and Protypotherium. Statistical Wilcoxon-rank tests between consecutive tooth pieces could be applied only to interatheriids, due to sample size $(n>4)$; they resulted in a significant difference between $\mathrm{p} 4 \mathrm{vs} . \mathrm{m} 1$ in Protypotherium $(W=1, p$-value $=0.02157)$ and p2 vs. p3 $(W=0, p$-value $=0.01219)$.

The sum of OTAs (excluding p1) is equivalent to the occlusal surface area (OSA). OSA values are significantly correlated with body mass $\left(n=16, r_{S}=0.9206, p\right.$-value $\left.<0.00001\right)$. The regression of the $\log$ (base 10) values was significant $\left(R^{2}=\right.$ 0.9899 , p-value $<0.00001)$ and the test for isometry of allo-

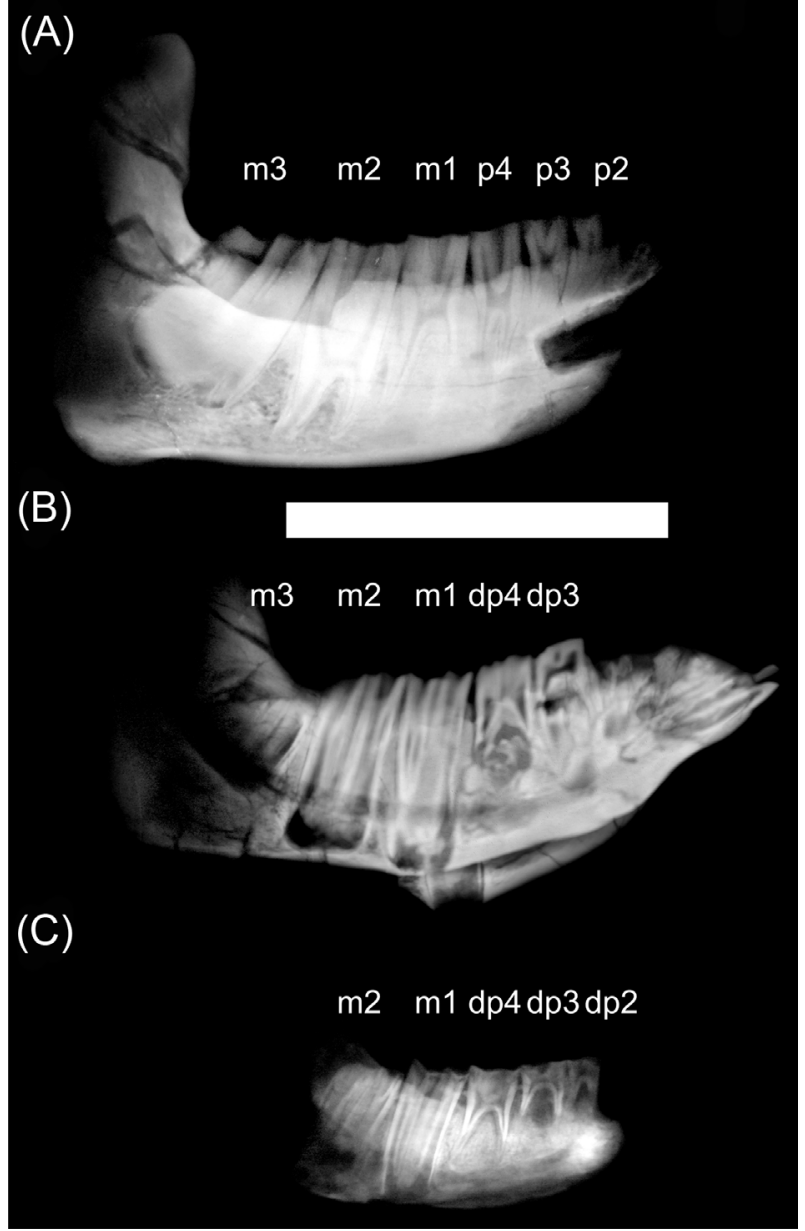

Figure 4 X-ray images of hemi-mandibles of Adinotherium ovinum at different ontogenetic stages: (A) MPM-PV 3660; (B) MPM-PV 3666; (C) MPM-PV 3544. Scale bar $=100 \mathrm{~mm}$.

metric coefficient resulted in a negative allometric tendency (slope $=0.553, F$ iso $_{(1,14)}=48.98, p$-value $\left.<0.00001\right)$.

The occlusal enamel length (OEL) in toxodontids increases progressively from $\mathrm{p} 1$ to $\mathrm{m} 3$. In typotheres, it increases from p1 to p4, but all molars show similar values (Table 2). Amongst interatheriids, the statistical Wilcoxon-rank tests between consecutive tooth pieces were tested in Protypotherium,

Table 1 Summary statistics [mean \pm one standard deviation; (n)] of teeth measurements (HI dimensionless units; Hm in mm; OTAs and OSA in $\mathrm{mm}^{2}$ ) and estimated body masses in $\mathrm{kg}$.

\begin{tabular}{|c|c|c|c|c|c|c|c|c|c|c|c|c|c|}
\hline & \multicolumn{4}{|c|}{ Hypsodonty } & \multicolumn{7}{|c|}{ Occlusal Tooth Area (OTA) } & \multirow[b]{2}{*}{ OSA } & \multirow[b]{2}{*}{ Body mas } \\
\hline & Hm1 & Hm2 & Hm3 & HI3 & p1 & p2 & p3 & p4 & m1 & m2 & m3 & & \\
\hline Adinotherium & $\begin{array}{l}22.11 \\
\pm 0.74 \\
(3)\end{array}$ & $\begin{array}{l}33.53 \\
\pm 1.21 \\
(3)\end{array}$ & $\begin{array}{l}37.64 \\
\pm 3.45 \\
(3)\end{array}$ & $\begin{array}{l}4.71 \\
\pm 0.47 \\
(3)\end{array}$ & $\begin{array}{l}14.71 \\
\pm 6.48 \\
(2)\end{array}$ & $\begin{array}{l}31.27 \\
\pm 8.72 \\
(3)\end{array}$ & $\begin{array}{l}52.06 \\
\pm 6.63 \\
(3)\end{array}$ & $\begin{array}{l}66.32 \\
\pm 5.43 \\
(3)\end{array}$ & $\begin{array}{l}91.59 \\
\pm 5.49 \\
(3)\end{array}$ & $\begin{array}{l}91.01 \\
\pm 2.3 \\
(3)\end{array}$ & $\begin{array}{l}87.1 \\
\pm 7.95 \\
(3)\end{array}$ & $\begin{array}{l}429.34 \\
\pm 7.95 \\
(3)\end{array}$ & $\begin{array}{l}102.82 \\
\pm 17.66 \\
\text { (3) }\end{array}$ \\
\hline Nesodon & $\begin{array}{l}30.38 \\
\pm 2.67 \\
(2)\end{array}$ & $\begin{array}{l}42.85 \\
\pm 1.62 \\
(2)\end{array}$ & $\begin{array}{l}53.67 \\
\pm 4.11 \\
(2)\end{array}$ & $\begin{array}{l}3.3 \\
\pm 0.22 \\
(2)\end{array}$ & & $\begin{array}{l}135.94 \\
\pm 18.03 \\
(2)\end{array}$ & $\begin{array}{l}200.82 \\
\pm 17.77 \\
(2)\end{array}$ & $\begin{array}{l}299.28 \\
\pm 10.23 \\
(2)\end{array}$ & $\begin{array}{l}389.53 \\
\pm 10.58 \\
(2)\end{array}$ & $\begin{array}{l}469.43 \\
\pm 44.33 \\
(2)\end{array}$ & $\begin{array}{l}526.83 \\
\pm 12.59 \\
(2)\end{array}$ & $\begin{array}{l}2021.82 \\
\pm 3.71 \\
\text { (2) }\end{array}$ & $\begin{array}{l}1157.76 \\
\pm 104.65 \\
(2)\end{array}$ \\
\hline Protypotherium & $\begin{array}{l}12.87 \\
\pm 1.01 \\
(4)\end{array}$ & $\begin{array}{l}12.93 \\
\pm 1.08 \\
(5)\end{array}$ & $\begin{array}{l}11.86 \\
\pm 1.15 \\
(5)\end{array}$ & $\begin{array}{l}4.09 \\
\pm 0.25 \\
(5)\end{array}$ & $\begin{array}{l}3.8 \\
\pm 1.24 \\
(4)\end{array}$ & $\begin{array}{l}5.07 \\
\pm 0.81 \\
(5)\end{array}$ & $\begin{array}{l}7.24 \\
\pm 1.68 \\
(5)\end{array}$ & $\begin{array}{l}9.68 \\
\pm 2.61 \\
(5)\end{array}$ & $\begin{array}{l}14.88 \\
\pm 2.14 \\
(5)\end{array}$ & $\begin{array}{l}14.25 \\
\pm 1.6 \\
(5)\end{array}$ & $\begin{array}{l}16.24 \\
\pm 3.68 \\
(5)\end{array}$ & $\begin{array}{l}67.35 \\
\pm 12.23 \\
(5)\end{array}$ & $\begin{array}{l}3.06 \\
\pm 0.77 \\
(5)\end{array}$ \\
\hline Interatherium & $\begin{array}{l}10.18 \\
\pm 1.07 \\
(5)\end{array}$ & $\begin{array}{l}9.98 \\
\pm 0.38 \\
(5)\end{array}$ & $\begin{array}{l}9.18 \\
\pm 0.8 \\
(4)\end{array}$ & $\begin{array}{l}3.33 \\
\pm 0.06 \\
(4)\end{array}$ & $\begin{array}{l}1.19 \\
\pm 0.41 \\
(4)\end{array}$ & $\begin{array}{l}3.84 \\
\pm 1.71 \\
(5)\end{array}$ & $\begin{array}{l}7.63 \\
\pm 1.27 \\
(5)\end{array}$ & $\begin{array}{l}8.81 \\
\pm 1.39 \\
(5)\end{array}$ & $\begin{array}{l}9.97 \\
\pm 1.6 \\
(5)\end{array}$ & $\begin{array}{l}9.75 \\
\pm 1.38 \\
(5)\end{array}$ & $\begin{array}{l}11.83 \\
\pm 1.35 \\
(4)\end{array}$ & $\begin{array}{l}51.98 \\
\pm 7.12 \\
(4)\end{array}$ & $\begin{array}{l}1.61 \\
\pm 0.41 \\
(5)\end{array}$ \\
\hline Hegetotherium & $\begin{array}{l}13.52 \\
\text { (1) }\end{array}$ & $\begin{array}{l}13.32 \\
\text { (1) }\end{array}$ & $\begin{array}{l}14.12 \\
\text { (1) }\end{array}$ & $\begin{array}{l}7.76 \\
(1)\end{array}$ & $\begin{array}{l}1.43 \\
(1)\end{array}$ & $\begin{array}{l}3.85 \\
(1)\end{array}$ & $\begin{array}{l}6.72 \\
(1)\end{array}$ & $\begin{array}{l}9.06 \\
(1)\end{array}$ & $\begin{array}{l}11.06 \\
\text { (1) }\end{array}$ & $\begin{array}{l}9.87 \\
(1)\end{array}$ & $\begin{array}{l}6.83 \\
(1)\end{array}$ & $\begin{array}{l}47.39 \\
\text { (1) }\end{array}$ & $\begin{array}{l}1.91 \\
(1)\end{array}$ \\
\hline
\end{tabular}


Table 2 Summary statistics [mean \pm one standard deviation; (n)] of teeth complexity measurement OEL in millimetres.

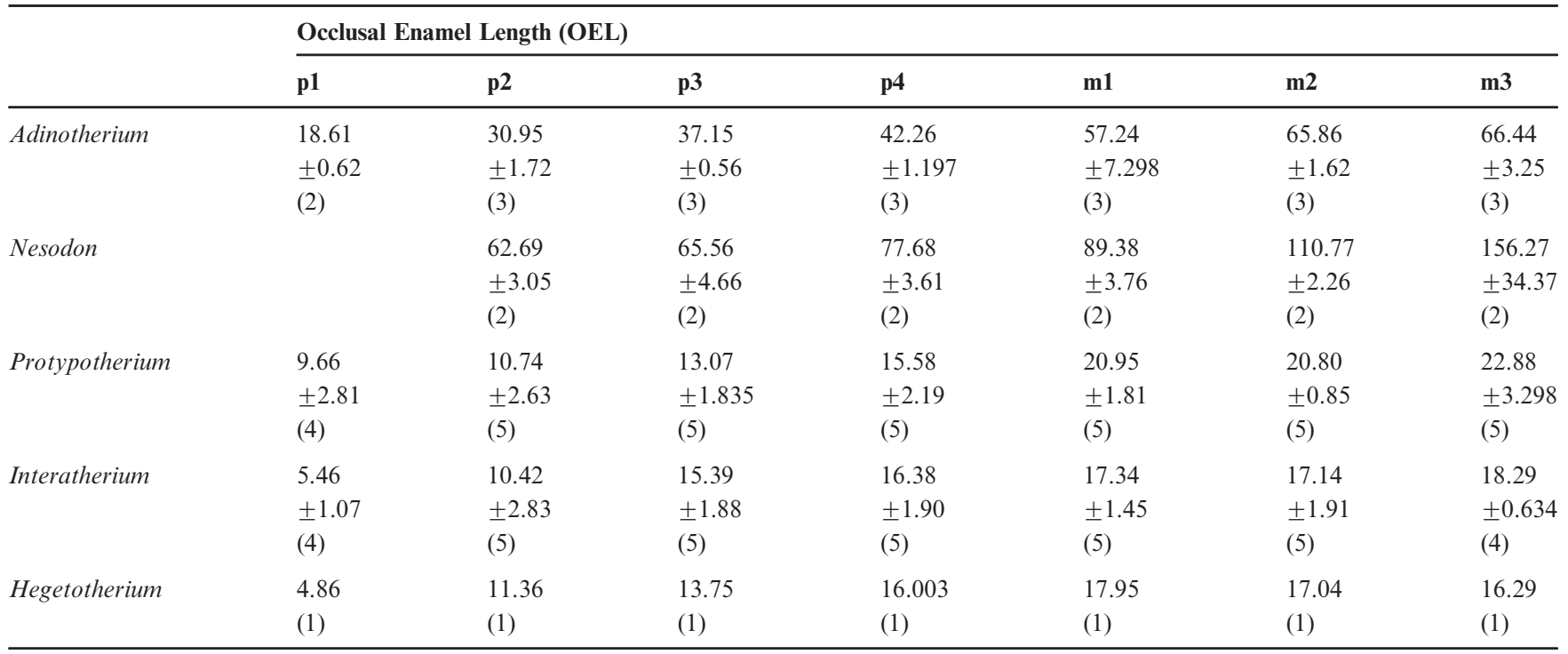

Table 3 Summary statistics [mean \pm one standard deviation; (n)] of teeth complexity measurement ECC as fractal dimension.

\begin{tabular}{|c|c|c|c|c|c|c|c|}
\hline & \multicolumn{7}{|c|}{ Enamel Crest Crenulation (ECC) - fractal dimension } \\
\hline & p1 & p2 & p3 & $\mathrm{p} 4$ & m1 & $\mathbf{m} 2$ & $\mathbf{m} 3$ \\
\hline Adinotherium & $\begin{array}{l}1.0916 \\
\pm 0.041 \\
\text { (2) }\end{array}$ & $\begin{array}{l}1.1244 \\
\pm 0.029 \\
\text { (3) }\end{array}$ & $\begin{array}{l}1.1372 \\
\pm 0.022 \\
(3)\end{array}$ & $\begin{array}{l}1.1337 \\
\pm 0.023 \\
\text { (3) }\end{array}$ & $\begin{array}{l}1.1512 \\
\pm 0.011 \\
(3)\end{array}$ & $\begin{array}{l}1.1709 \\
\pm 0.011 \\
(3)\end{array}$ & $\begin{array}{l}1.1803 \\
\pm 0.012 \\
(3)\end{array}$ \\
\hline Nesodon & & $\begin{array}{l}1.0962 \\
\pm 0.005 \\
\text { (2) }\end{array}$ & $\begin{array}{l}1.0586 \\
\pm 0.053 \\
\text { (2) }\end{array}$ & $\begin{array}{l}1.0819 \\
\pm 0.028 \\
\text { (2) }\end{array}$ & $\begin{array}{l}1.097 \\
\pm 0.015 \\
\text { (2) }\end{array}$ & $\begin{array}{l}1.1812 \\
\pm 0.001 \\
\text { (2) }\end{array}$ & $\begin{array}{l}1.209 \\
\pm 0.041 \\
(2)\end{array}$ \\
\hline Protypotherium & $\begin{array}{l}1.0669 \\
\pm 0.06 \\
(4)\end{array}$ & $\begin{array}{l}1.0725 \\
\pm 0.057 \\
(5)\end{array}$ & $\begin{array}{l}1.092 \\
\pm 0.034 \\
(5)\end{array}$ & $\begin{array}{l}1.0705 \\
\pm 0.009 \\
(5)\end{array}$ & $\begin{array}{l}1.0885 \\
\pm 0.022 \\
(5)\end{array}$ & $\begin{array}{l}1.0907 \\
\pm 0.024 \\
(5)\end{array}$ & $\begin{array}{l}1.0999 \\
\pm 0.023 \\
(5)\end{array}$ \\
\hline Interatherium & $\begin{array}{l}1.0927 \\
\pm 0.039 \\
(4)\end{array}$ & $\begin{array}{l}1.0984 \\
\pm 0.03 \\
(5)\end{array}$ & $\begin{array}{l}1.1047 \\
\pm 0.011 \\
(5)\end{array}$ & $\begin{array}{l}1.1058 \\
\pm 0.002 \\
(5)\end{array}$ & $\begin{array}{l}1.0968 \\
\pm 0.018 \\
(5)\end{array}$ & $\begin{array}{l}1.0972 \\
\pm 0.039 \\
(5)\end{array}$ & $\begin{array}{l}1.1004 \\
\pm 0.03 \\
(4)\end{array}$ \\
\hline Hegetotherium & $\begin{array}{l}1.0548 \\
\text { (1) }\end{array}$ & $\begin{array}{l}1.1154 \\
\text { (1) }\end{array}$ & $\begin{array}{l}1.1251 \\
\text { (1) }\end{array}$ & $\begin{array}{l}1.1081 \\
\text { (1) }\end{array}$ & $\begin{array}{l}1.1164 \\
\text { (1) }\end{array}$ & $\begin{array}{l}1.1354 \\
\text { (1) }\end{array}$ & $\begin{array}{l}1.1673 \\
\text { (1) }\end{array}$ \\
\hline
\end{tabular}

Table 4 One-way ANOVA, with correction for pseudo-replication and multiple comparisons for differences in D between teeth.

\begin{tabular}{lcll}
\hline Taxon & $\boldsymbol{F}$ - $\boldsymbol{d} \boldsymbol{f}(\mathbf{g p}, \mathbf{r e s})$ & $\boldsymbol{p}$-value & Multiple comparisons \\
\hline Adinotherium & $3.88(5,10)$ & 0.0324 & $\mathrm{pm} 2=\mathrm{a} ; \mathrm{pm} 3=\mathrm{a}, \mathrm{c} ; \mathrm{pm} 4=\mathrm{a}, \mathrm{b} ; \mathrm{m} 1=\mathrm{a}, \mathrm{c} ; \mathrm{m} 2=\mathrm{b}, \mathrm{c} ; \mathrm{m} 3=\mathrm{c}$ \\
Nesodon & $13.961(5,5)$ & 0.0058 & $\mathrm{pm} 2=\mathrm{a} ; \mathrm{pm} 3=\mathrm{a} ; \mathrm{pm} 4=\mathrm{a} ; \mathrm{m} 1=\mathrm{a} ; \mathrm{m} 2=\mathrm{m} 3=\mathrm{b}$ \\
Protypotherium & $0.898(5,20)$ & 0.501 & $\mathrm{pm} 2=\mathrm{pm} 3=\mathrm{pm} 4=\mathrm{m} 1=\mathrm{m} 2=\mathrm{m} 3=\mathrm{a}$ \\
Interatherium & $1.522(5,15)$ & 0.242 & $\mathrm{pm} 2=\mathrm{pm} 3=\mathrm{pm} 4=\mathrm{m} 1=\mathrm{m} 2=\mathrm{m} 3=\mathrm{a}$ \\
Hegetotherium* & $89.44(5,55)$ & 0.0001 & $\mathrm{pm} 2=\mathrm{a} ; \mathrm{pm} 3=\mathrm{b} ; \mathrm{pm} 4=\mathrm{a} ; \mathrm{m} 1=\mathrm{a}, \mathrm{b} ; \mathrm{m} 2=\mathrm{c} ; \mathrm{m} 3=\mathrm{d}$ \\
\hline
\end{tabular}

Letters: single letters (starting with a) indicate significant values from the lowest to the highest mean; combined letters (e.g., a, b) indicate no significant differences with referenced values (i.e., a and b). ${ }^{*}$ on Hegetotherium, analysis was performed on the twelve replicates for teeth.

showing a significant difference between $\mathrm{p} 4 \mathrm{vs}$. $\mathrm{m} 1(W=1$, $p$-value $=0.0216)$; whilst for Interatherium the tests showed a significant difference between 1 vs. p2 $(W=1, p$-value $=$ $0.0373)$ and 2 vs. p3 $(W=1, p$-value $=0.02157)$.

The fractal dimension (D) obtained for known fractals does not differ significantly from their theoretical values (t-test), with a very good accuracy to the second decimal place. For example, for the Gosper's isle edge, we obtained a $\mathrm{D}=1.0681$ $\left(D_{\text {teo }}=1.0689\right)$ and for the Koch curve, a $\mathrm{D}=1.2587\left(\mathrm{D}_{\text {teo }}=\right.$
1.2619). In the middle range, the Viscek fractal resulted in a $\mathrm{D}=1.4662\left(\mathrm{D}_{\text {teo }}=1.4649\right)$, the Sierpinski triangle in a $\mathrm{D}=$ $1.5869\left(\mathrm{D}_{\text {teo }}=1.585\right)$ and the Sierpinski carpet in a $\mathrm{D}=$ $1.8918\left(\mathrm{D}_{\text {teo }}=1.8928\right)$. The tooth enamel crest complexity (ECC) of all genera analysed ranged between 1.05 and 1.2; i.e., between Gosper's isle edge and the Koch curve (Table 3). The higher values are reached by $\mathrm{m} 2$ and $\mathrm{m} 3$ in toxodontids ( 1.19), whilst premolars of interatheriids and Nesodon show the lowest values $(\sim 1.08$; Table 3$)$. The One-Way ANOVA 
(A)

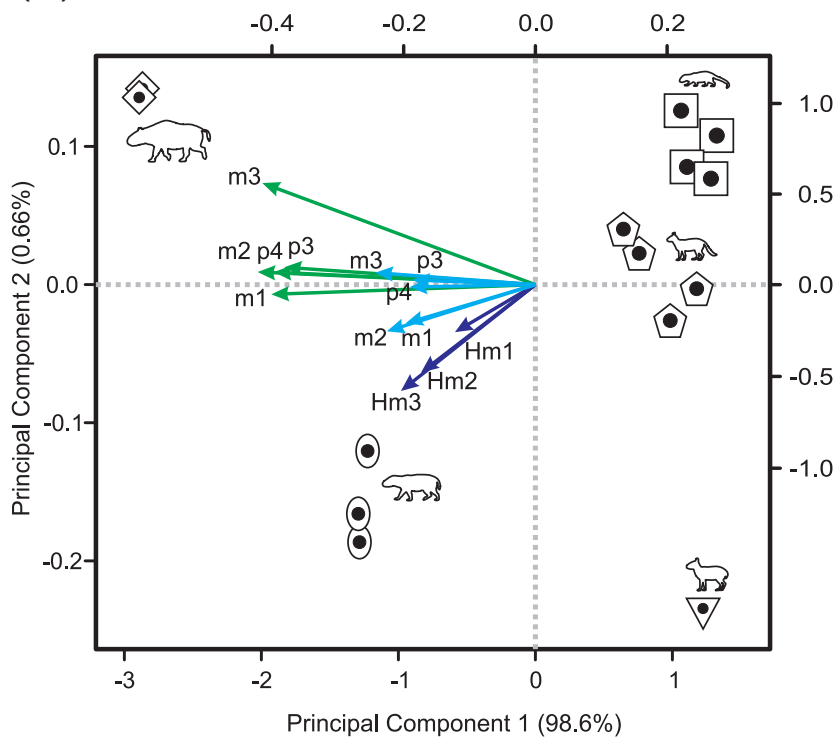

(B)

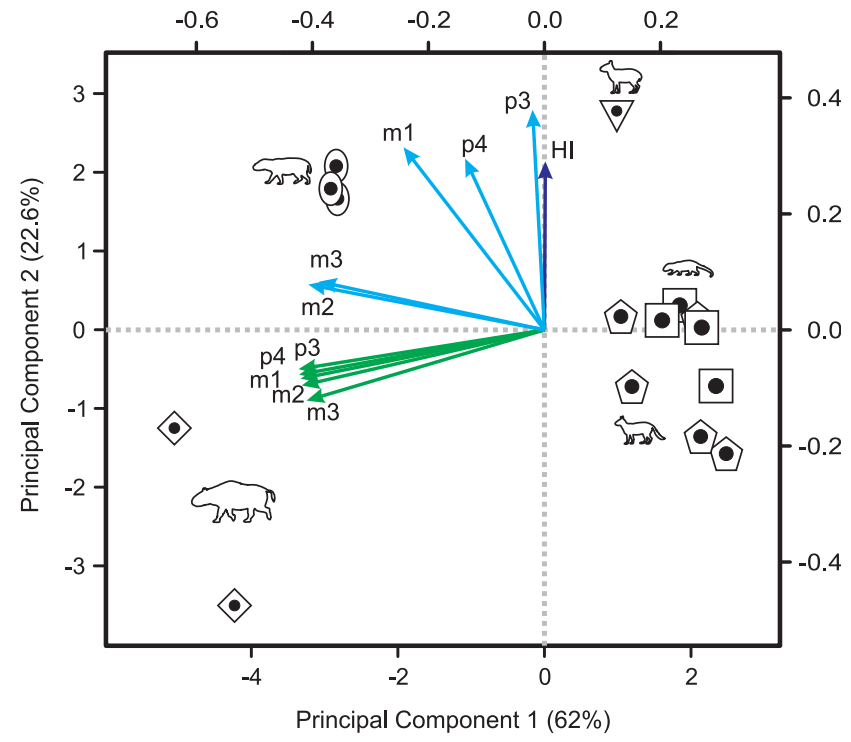

Figure 5 Morpho spaces depicted by the two first principal components: (A) PCA on OTA and OEL from p3 to $\mathrm{m} 3$, plus molar heights ( $\mathrm{Hm} 1$ to $\mathrm{Hm} 3$ ); (B) PCA on OTA, ECC and HI from $\mathrm{p} 3$ to m3. Arrows indicate the pc-loadings (green = OTA; cyan = OEL (in A) and ECC (in B); blue = HI). The pc-scores scale at the bottom and left axes. The pc-loadings scale at the upper and right axes. Symbols: square = Interatherium; rhombus = Nesodon $;$ pentagon $=$ Protypotherium $;$ oval $=$ Adinotherium $;$ inverse triangle $=$ Hegetotherium .

with correction for pseudo-replications was significant only for toxodontids and Hegetotherium (Table 4). The post-hoc Tuckey test indicated differences between each piece along the tooth row. Among toxodontids, Adinotherium shows a progressive change in complexity, being lower in the anterior premolars, intermediate in the premolar-molar transition, and higher in the posterior molars; whilst in Nesodon, $\mathrm{m} 2$ and $\mathrm{m} 3$ are markedly more complex than the premolars and $\mathrm{m} 1$. In typotheres, there are two patterns: one more similar to toxodontids (i.e., progressive increasing values from p1 to $\mathrm{m} 3$ ) in Hegetotherium; and the other with uniform values along the tooth row in both interatheriids (Table 4).

\subsection{Principal components analysis}

The principal component analysis of OEL and OTA from $\mathrm{p} 3$ to $\mathrm{m} 3$, plus molar heights, results in almost all variance being explained by PC1 $(98.58 \%)$, which correlates negatively with body mass $\left(r_{p}=-0.997, p\right.$-value $\left.<0.0001\right)$. All the variables have negative values, with OTAs being the highest $(\sim-0.4)$ and OELs and molar heights the lowest $(\sim-0.2)$. The PC2 accounted for only $0.66 \%$ of the variance, but is negatively correlated with HI $\left(r_{\mathrm{p}}=-0.851, p\right.$-value $\left.<0.001\right)$. The $\mathrm{m} 2$ and $\mathrm{m} 3$ heights have the most negative values $(\sim-0.5)$, whilst the $\mathrm{m} 3$ OTA has the most positive one $(\sim 0.5)$. The morphospace depicted by these two components (Fig. 5A) clusters interatheriids on the first quadrant (low BM and HI), Nesodon on the second (high BM and low HI), Adinotherium on the third (high $\mathrm{BM}$ and $\mathrm{HI}$ ) and Hegetotherium on the fourth (low BM and high $\mathrm{HI}$ ).

The principal component analysis of OTA, ECC from $\mathrm{p} 3$ to $\mathrm{m} 3$, plus HI, results in the first two components accounting for $\sim 90 \%$ of the cumulative variance, with the PC1 ( 62\%) correlating negatively with body mass $\left(r_{p}=-0.98\right.$, $p$-value $<$ 0.0001). With the exception of ECC of p3 and p4 and HI, the remaining variables (ECC and OTA) have high negative loadings (mostly -0.36; and ECC of $\mathrm{m} 1 \sim-0.2)$. On PC2 (22.6 $\%)$, which is uncorrelated with $\mathrm{BM}\left(r_{p}=-0.17, p\right.$-value $=$ $0.548)$, the ECC of $\mathrm{p} 3$ has the highest loading (0.55), followed by the HI and ECC of p4 and $\mathrm{m} 1(\sim 0.42)$, whilst the OTAs have the lowest loading $(-0.18)$. The morphospace depicted by these two components gathers large notoungulates on the negative side of $\mathrm{PC} 1$ and small ones on the positive side (Fig. 5B). On PC2, the most hypsodont, with a higher crown complexity pattern of $\mathrm{p} 3$ to $\mathrm{m} 1$ (Hegetotherium and Adinotherium), lie on the positive side, whereas those less hypsodont and with a more simplified crown pattern, but with greater occlusal surface area (Nesodon and interatheriids), lie on the negative side.

\section{Discussion}

X-ray images clearly show that premolars and molars of typotheres are high-crowned and ever-growing (euhypsodonty sensu Mones 1982). In addition, $\mathrm{p} 3-\mathrm{m} 3$ have a similar crown height, so it should be expected that HI calculated on molars (even when they have suffered wear) will not vary significantly during the life span. The premolars and molars of nesodontines are also high-crowned but all, except $\mathrm{m} 3$, have finite growth. X-ray images reveal that at early ontogenetic stages, $\mathrm{m} 1$ and $\mathrm{m} 2$ are rootless and occupy the complete mandibular ramus height (Fig. 4C). Later, as they develop roots (Fig. 4A), functional hypsodonty is achieved by the crown emerging (not growing) from a high mandibular ramus (protohypsodonty sensu Mones 1982). Consequently, HI would vary according to the ontogenetic stage, being higher in a fully formed tooth before emerging than in an emerged one (see Fig. 4). Instead, $\mathrm{m} 3$ seems to be ever-growing throughout the life span, or at least until advanced adult stages (as the trigonid eventually starts to develop a root whilst the talonid remains rootless; see also Fig. 2A). Due to these reasons, we focus on $\mathrm{m} 3$ to compare results of $\mathrm{HI}$ between toxodontids and typotheres. The obtained values of HI are comparable with those of Janis (1988) for artiodactyls and perissodactyls, even when calculated on a worn $\mathrm{m} 3$ (Cassini et al. 2011). As it was previously reported by Cassini et al. (2011), all Santacrucian notoungulates have an HI comparable with those of extant ungulates dwelling in open or mixed habitats (HI $>2$; see Mendoza \& Palmqvist 2008).

The total occlusal surface area (OSA) is highly correlated with body mass, as has been previously reported for upper 
cheek teeth of notoungulates (Cassini et al. 2012a) and also for other herbivorous mammals (Vizcaíno et al. 2006, 2011; Famoso et al. 2013). In the present study, this relationship follows a negative allometric trend, opposed to the positive allometry reported by Cassini et al. (2012a) for upper cheek teeth. This implies that large notoungulates (i.e., Adinotherium, $\sim 100 \mathrm{~kg}$ and Nesodon, $\sim 1000 \mathrm{~kg}$; Table 1) have OSA proportionally larger on the upper cheek teeth and smaller on the lower cheek teeth than expected for their body size. Certainly, this may have mechanical implications; for instance, to emphasise the lateral component on chewing movements, as lower teeth have to travel against the occlusal surface of the upper teeth more than in typotheres $(<10 \mathrm{~kg}$; Table 1$)$.

Instead, the implications on dietary preferences and digestive physiology remain obscure. As mentioned above, it has been suggested that amongst ungulates and other herbivorous mammals, OSA is larger in grazers than in browsers, constitutes a measure of the capacity to process food in the oral cavity and reflects aspects of feeding physiology and metabolism (Janis 1988, 1990, 1995; Janis \& Constable 1993; Pérez-Barbería \& Gordon 1998b; Mendoza et al. 2002; Vizcaíno et al. 2006, 2011). Based on these concepts, Cassini et al. (2012a) proposed that notoungulates had better digestive capabilities than other native South American ungulates (litopterns); amongst them, Toxodontia and Typotheria tend to have greater and lower OSA, respectively, than predicted for an herbivorous mammal of equivalent size. However, several of the mentioned contributions calculated OSA on the upper cheek teeth instead of the lower, as we do here, which stresses the need for further research on this matter.

The occlusal tooth area (OTA) shows a positive correlation with body mass, as was reported for extant ungulates by Famoso et al. (2013), although following different patterns along the lower tooth row between taxa. In the typotheres Interatherium and Hegetotherium, both with molarised p3 and p4, there is a gradual increase in OTA from $\mathrm{p} 3$ to $\mathrm{m} 3$. On the contrary, in Protypotherium and toxodontids, in which premolars are not or are less molarised, the premolars have a lower OTA than the molars. As proposed by Famoso et al. (2013), OTA has a strong correlation with the enamel length (OEL) in extant ungulates. Therefore, the analysis of these two variables, OTA (and their sum OSA) and OEL, leads to the same conclusion. In our analyses, OEL and OTA are strongly correlated and follow a similar pattern, scaling with body mass and increasing in a similar way from $\mathrm{p} 1$ to $\mathrm{m} 3$. In accordance with Famoso et al. (2013), OEL seems to be controlled as much by diet preference (grass or browse) as by body size and phylogeny (particularly the constraints on its digestive strategy), and therefore it cannot be used on its own to determine feeding strategy.

The enamel crest complexity (ECC) is indicative of how the enamel edges of cheek teeth fill up the available occlusal surface area. As the enamel edges become more convoluted, they become more complex, and the fractal dimension (D) is expected to be between 1 and 2. The ECC obtained for Santacrucian notoungulates are between 1.05 and 1.20, lower than that of the Late Miocene giant caviomorph rodent Eumegamys paranensis (Candela et al. 2013) ( 1.5) and the Proboscidea Elephas maximus $(\mathrm{D}=1.21)$ and Mammuthus columbi $(\mathrm{D}=$ 1.36) (Stone \& Telford 2005). Within notoungulates, cheek teeth of typotheres are less complex than those of toxodontids. In interatheriids, tooth complexity is similar along the tooth row, whilst in Hegetotherium and toxodontids, complexity increases from premolars to molars. As proposed by Candela et al. (2013), the dissimilar degree of complexity along the cheek tooth row probably reflects different capacities for breaking food in each masticatory cycle. Whilst in interatheriids this capacity must have been nearly equally distributed along the cheek tooth row, in Hegetotherium and the toxodontids it must have been emphasised in the last molars. As also proposed for Eumegamys $(\sim 140 \mathrm{~kg})$, it is expected that larger animals require higher tooth complexity to process large amounts of food daily.

The relationship with other dental variables such as OTA (and consequently body mass) and HI was summarised by the PCA. The ECC of p3 to $\mathrm{m} 1$ (anterior to middle tooth row) and $\mathrm{HI}$ do not correlate with occlusal surface area and, therefore, are size independent. Instead, the ECC of $\mathrm{m} 2$ and $\mathrm{m} 3$ correlate with occlusal area and body mass. This indicates that the most hypsodont Santacrucian notoungulates (Hegetotherium and Adinotherium) have relatively less occlusal area and more tooth complexity on the anterior to middle parts of the tooth row than other genera. Amongst the less hypsodont taxa, Nesodon and Protypotherium have relatively larger occlusal areas, but less tooth complexity, in the anterior to middle parts of the tooth row than do Interatherium.

Among typotheres, all being euhypsodont, Interatherium has the lower HI but may compensate that with more molarised p3 and p4 (with OTA and ECC similar to those of molars) than Protypotherium. Hegetotherium has less occlusal area, but seems to compensate this with more hypsodont cheek teeth, molarised p3 and p4, and more complex molars. Within toxodontids, Nesodon has lower HI that Adinotherium, but both tend to simplify the occlusal pattern of $\mathrm{m} 1$ and $\mathrm{m} 2$ as they wear, maybe as a result of a protohypsodonty. In contrast, the $\mathrm{m} 3$, which is an ever-growing tooth, has a greater complexity crown pattern, being relatively higher in Nesodon.

Cassini (2013), based on ecomorphological analyses of 3D landmarks, proposed that all Santacrucian notoungulates inhabited open habitats, with Nesodon more likely dwelling in a mixed habitat (but see Townsend \& Croft 2008). Whilst the interatheriids must have fed mainly on grasses, the others would have consumed grasses and leaves, depending on their availability. Madden (1997) proposed that the most complex molar crowns in toxodontids would have provided great shearing ability to break down the grasses. The present results seem to be coherent with these previous hypotheses. The hypsodont teeth of Santacrucian notoungulates indicate high rates of tooth wear, perhaps in response to an increase of abrasives consumed with the food (Billet et al. 2009) in open or mixed environments. According to Evans et al. (2007), functional design traits, such as tooth occlusal area and complexity, depend on the required degree of mechanical processing, which in turn depends on the difficulty with which mechanical and chemical breakdown of different kinds of food can be achieved (as well as metabolic requirements). Therefore, the chewing effort (e.g., grinding) depends on the toughness of the plant consumed; for example, a given particle size of tough food (such as grasses or other fibrous plants) can be obtained by investing less chewing energy when processed by a more complex tooth.

As a working hypothesis, we propose that these three traits (i.e., tooth occlusal surface area and complexity, and tooth crown height) are integrated as a complex in which a reduction in one feature is compensated by an increase in one or two of the others (partially in Vizcaíno et al. 2006; and Reguero et al. 2010). As a consequence, although the hypsodonty index has been considered a powerful tool for palaeoecological reconstructions, it should not be evaluated alone, as it is also true for the other two.

\section{Conclusions}

On the available evidence, the tooth occlusal complexity, occlusal surface area and hypsodonty in the Santacrucian 
notoungulates could have been adaptations towards durability of teeth and increased functional efficiency for grinding food processing. Whilst occlusal surface area is strongly influenced by body mass (and perhaps digestive capabilities), tooth complexity and hypsodonty are size independent. Occlusal complexity, occlusal area and hypsodonty seem to compensate each other in order to process relatively large amounts of demanding food (grass), or even a variety of diets (as those of the mixed feeders) that include great quantities of environmental abrasives, as in open and mixed habitats.

\section{Acknowledgments}

The authors wish to thank following people and institutions: the Editors of this Special Issue on Form, Function and Palaeobiology, for inviting us to participate; the Dirección de Patrimonio Cultural and Museo Regional Provincial Padre M. J. Molina (Río Gallegos, Argentina), for granting access to the vertebrate palaeontological collections; and the reviewers M. Reguero and E. Cerdeño, for valuable suggestions and corrections that greatly enhanced this manuscript.

This is a contribution to the following projects: PICT 20130389 (ANPCyT) and UNLP N750 (to SFV); the National Science Foundation (to R. F. Kay); and the National Geographic Society (to SFV and R. F. Kay). GHC dedicates this paper to the memory of M. Cristina Escobar García, for her unconditional support through the toughest times.

\section{References}

Billet, G. 2010. New Observations on the Skull of Pyrotherium (Pyrotheria, Mammalia) and New Phylogenetic Hypotheses on South American Ungulates. Journal of Mammalian Evolution 17, 21-59.

Billet, G., Blondel, C. \& de Muizon, C. D. 2009. Dental microwear analysis of notoungulates (Mammalia) from Salla (Late Oligocene, Bolivia) and discussion on their precocious hypsodonty. Palaeogeography, Palaeoclimatology, Palaeoecology 274, 114-24.

Bond, M. 1986. Los ungulados fósiles de Argentina: evolución y paleoambientes. In Simposio "Evolución de los Vertebrados Cenozoicos", IV Cogreso Argentino de Paleontologia y Bioestratigrafia Actas 2 , 187-90. (Mendoza, 23-27 Noviembre, 1986.)

Candela, A. M., Cassini, G. H. \& Nasif, N. L. 2013. Fractal dimension and cheek teeth crown complexity in the giant rodent Eumegamys paranensis. Lethaia 46, 369-77.

Cassini, G. H. 2013. Skull geometric morphometrics and paleoecology of Santacrucian (late early Miocene; Patagonia) native ungulates (Astrapotheria, Litopterna and Notoungulata). Ameghiniana 50, 193-216.

Cassini, G. H., Mendoza, M., Vizcaíno, S. F. \& Bargo, M. S. 2011. Inferring habitat and feeding behaviour of early Miocene notoungulates from Patagonia. Lethaia 44, 153-65.

Cassini, G. H., Cerceño, M. E., Villafañe, A. L. \& Muñoz, N. A. 2012a. Paleobiology of Santacrucian native ungulates (Meridiungulata: Astrapotheria, Litopterna and Notoungulata. In Vizcaíno, S. F., Kay, R. \& Bargo, M. S. (eds) Early Miocene Paleobiology in Patagonia: high-latitude paleocommunities of the Santa Cruz Formation, 243-86. Cambridge, UK \& New York: Cambridge University Press. $\mathrm{x}+370 \mathrm{pp}$.

Cassini, G. H., Vizcaíno, S. F. \& Bargo, M. S. 2012b. Body mass estimation in Early Miocene native South American ungulates: a predictive equation based on 3D landmarks. Journal of Zoology 287, 53-64.

Cassini, G. H., Flores, D. A. \& Vizcaíno, S. F. 2012c. Postnatal ontogenetic scaling of Nesodontine (Notoungulata, Toxodontidae) cranial morphology. Acta Zoologica (Stockholm) 93, 249-59.

Cassini, G. H. \& Vizcaino, S. F. 2012. An Approach to the Biomechanics of the Masticatory Apparatus of Early Miocene (Santacrucian Age) South American Ungulates (Astrapotheria, Litopterna, and Notoungulata): Moment Arm Estimation Based on 3D Landmarks. Journal of Mammalian Evolution 19, 9-25.

Cifelli, R. L. 1993. The phylogeny of the native South American ungulates. In Szalay, F. S., Novacek, M. J. \& Mckenna, M. C. (eds) Mammal Phylogeny: Placentals, 195-216. New York and London: Springer-Verlag. xi +321 pp.

Croft, D. A. 1999. Placentals: endemic South American ungulates. In Singer, R. (ed.) The Encyclopedia of Paleontology, 890-906. Chicago: Fitzroy-Dearborn. 1550 pp.

Croft, D. A. 2001. Cenozoic environmental change in South America as indicated by mammalian body size distributions (cenograms). Diversity and Distributions 7, 271-87.

Croft, D. A. \& Anderson, L. C. 2008. Locomotion in the extinct notoungulate Protypotherium. Palaeontologia Electronica 11, 1-20.

Croft, D. A. \& Weinstein, D. 2008. The first application of the mesowear method to endemic South American ungulates (Notoungulata). Palaeogeography, Palaeoclimatology, Palaeoecology 269, 103-14.

Elissamburu, A. 2004. Morphometric and morphofunctional analysis of the apendicular skeleton of Paedotherium (Mammalia, Notoungulata). Ameghiniana 41, 363-80.

Elissamburu, A. 2010. Estudio biomecánico y morfofuncional del esqueleto apendicular de Homalodotherium Flower, 1873 (Mammalia, Notoungulata). Ameghiniana 47, 25-43.

Elissamburu, A. 2012. Estimación de la masa corporal en géneros del Orden Notoungulata. Estudios Geológicos (Madrid) 68, 91-111.

Evans, A. R., Wilson, G. P., Fortelius, M. \& Jernvall, J. 2007. Highlevel similarity of dentitions in carnivorans and rodents. Nature 445, 78-81.

Famoso, N. A., Feranec, R. S. \& Davis, E. B. 2013. Occlusal enamel complexity and its implications for lophodonty, hypsodony, body mass and diet in extinct and extant ungulates. Palaeogeography, Palaeoclimatology, Palaeoecology 387, 211-16.

Famoso, N. A., Davis, E. B., Feranec, R. S., Hopkins, S. S. B. \& Price, S. A. 2016. Are Hypsodonty and Occlusal Enamel Complexity Evolutionarily Correlated in Ungulates? Journal of Mammalian Evolution 23(1), 43-47.

Fleagle, J. G., Perkins, M. E., Heizler, M. T., Nash, B., Bown, T. M., Tauber, A. A., Dozo, M. T. \& Tejedor, M. F. 2012. Absolute and relative ages of fossil localities in the Santa Cruz and Pinturas Formations. In Vizcaíno, S. F., Kay, R., Bargo, M. S. (eds) Early Miocene Paleobiology in Patagonia: high-latitude paleocommunities of the Santa Cruz Formation, 41-58. Cambridge, UK \& New York: Cambridge University Press. 370 pp.

Flynn, J. J., Wyss, A. R., Croft, D. A. \& Charrier, R. 2003. The Tinguiririca Fauna, Chile: biochronology, paleoecology, biogeography, and a new earliest Oligocene South American Land Mammal 'Age'. Palaeogeography, Palaeoclimatology, Palaeoecology 195, 229-59.

Flynn, J. J. \& Wyss, A. R. 1998. Recent advances in South American mammalian paleontology. Trends in Ecology \& Evolution 13, 44954.

Giannini, N. \& García-López, D. 2014. Ecomorphology of Mammalian Fossil Lineages: Identifying Morphotypes in a Case Study of Endemic South American Ungulates. Journal of Mammalian Evolution 21, 195-212.

Janis, C. M. 1988. An estimation of tooth volume and hypsodonty indices in Ungulate Mammals, and the correlation of these factors with dietary preference. In Russell, D. E., Santoro, J. P. \& Sigogneau-Russell, D. (eds) Teeth Revisited: Proceedings of the VII International Symposium on Dental Morphology, Paris 1986. Mémoires du Muséum national d'Histoire naturelle (série C), Sciences de la Terre 53, 367-87. Paris: Editions du Muséum. $462 \mathrm{pp}$.

Janis, C. M. 1990. Correlation of cranial and dental variables with dietary preferences: a comparison of macropodoid and ungulate mammals. In Turner, S. \& Thulborn, A. (eds) Problems in vertebrate Biology and Phylogeny - an Autralian Perspective. Memoirs of the Queensland Museum 28(1), 349-66.

Janis, C. M. 1995. Correlations between craniodental morphology and feeding behavior in ungulates: reciprocal illumination between living and fossil taxa. In Thomason, J. J. (ed.) Functional Morphology in Vertebrate Paleontology, 76-98. Cambridge: Cambridge University Press. xi +277 pp.

Janis, C. M. \& Constable, E. 1993. Can ungulate craniodental features determine digestive physiology? Journal of Vertebrate Paleontology 13, 43A.

Kay, R. F., Madden, R. H., Vucetich, M. G., Carlini, A. A., Mazzoni, M. M., Re, G. H., Heizler, M. \& Sandeman, H. 1999. Revised Geochronology of the Casamayoran South American Land Mammal Age: Climatic and Biotic Implications. Proceedings of the National Academy of Sciences of the United States of America 96, 13235-40.

Kay, R., Vizcaíno, S. F. \& Bargo, M. S. 2012. A review of the paleoenvironment and paleoecology of the Miocene Santa Cruz 
Formation. In Vizcaíno, S. F., Kay, R., Bargo, M. S. (eds) Early Miocene Paleobiology in Patagonia: high-latitude paleocommunities of the Santa Cruz Formation, 331-64. Cambridge, UK \& New York: Cambridge University Press. $\mathrm{x}+370 \mathrm{pp}$.

MacFadden, B. J. 2000. Cenozoic mammalian herbivores from the Americas: Reconstructing ancient diets and terrestrial communities. Annual Review of Ecology and Systematics 31, 33-59.

Madden, R. H. 1997. A new toxodontid notoungulate. In Kay, R. F., Madden, R. H., Cifelli, R. L. \& Flynn, J. J. (eds) Vertebrate Paleontology in the Neotropics: The Miocene Fauna of La Venta, Colombia, 335-54. Washington, DC: Smithsonian Institution Press. xvi +592 pp.

Madden, R. H. 2015. Hypsodonty in Mammals: evolution, geomorphology, and the role of earth surface processes. Cambridge, UK: Cambridge University Press. $\mathrm{xx}+423 \mathrm{pp}$.

Mendoza, M., Janis, C. M. \& Palmqvist, P. 2002. Characterizing complex craniodental patterns related to feeding behaviour in ungulates: A multivariate approach. Journal of Zoology 258, 22346.

Mendoza, M. \& Palmqvist, P. 2008. Hypsodonty in ungulates: An adaptation for grass consumption or for foraging in open habitat? Journal of Zoology 274, 134-42.

Mones, A. 1982. An equivocal nomenclature: What means hypsodonty? Paläontologische Zeitschrift. 56, 107-11.

Patterson, B. \& Pascual, R. 1968. The fossil mammal fauna of South America. The Quarterly Review of Biology 43, 409-51.

Patterson, B. \& Pascual, R. 1972. The fossil mammal fauna of South America. In Keast, A., Erk, F. C. \& Glass, B. (eds) Evolution, Mammals, and Southern Continents 247-309. Albany: University of New York State Press.

Pérez-Barbería, F. J. \& Gordon, I. J. 1998a. The influence of molar occlusal surface area on the voluntary intake, digestion, chewing behaviour and diet selection of red deer (Cervus elaphus). Journal of Zoology 245, 307-16.

Pérez-Barbería, F. J. \& Gordon, I. J. 1998b. Factors affecting food comminution during chewing in ruminants: A review. Biological Journal of the Linnean Society 63, 233-56.

Pérez-Barbería, F. J. \& Gordon, I. J. 2001. Relationships between oral morphology and feeding style in the ungulata: A phylogenetically controlled evaluation. Proceedings of the Royal Society B: Biological Sciences 268, 1023-32.

Perkins, M. E., Fleagle, J. G., Heizler, M. T., Nash, B., Bown, T. M., Tauber, A. A. \& Dozo, M. T. 2012. Tephrochronology of the Miocene Santa Cruz and Pinturas Formations, Argentina. In Vizcaíno, S. F., Kay, R., Bargo, M. S. (eds) Early Miocene Paleobiology in Patagonia: high-latitude paleocommunities of the Santa Cruz Formation, 23-40. Cambridge, UK \& New York: Cambridge University Press. $\mathrm{x}+370 \mathrm{pp}$.

Rasband, W. S. 1997-2007. ImageJ. Bethesda, MD: US National Institute of Health.

Reguero, M. A., Candela, A. M. \& Cassini, G. H. 2010. Hypsodonty and body size in rodent-like notoungulates. In Madden, R. H., Carlini, A. A., Vucetich, M. G. \& Kay, R. F. (eds) The Paleontology of Gran Barranca: Evolution and Environmental Change through the Middle Cenozoic of Patagonia, 362-71. Cambridge: Cambridge University Press. $458 \mathrm{pp}$.

Scarano, A. C., Carlini, A. A. \& Illius, A. W. 2011. Interatheriidae (Typotheria: Notoungulata), body size and paleoecology characterization. Mammalian Biology 76, 109-114.

Scott, W. B. 1937. A history of land mammals in the Western Hemisphere. New York: Macmillan. xiv + 786 pp.

Shapiro, S. S. \& Wilk, M. B. 1965. An analysis of variance test for normality (complete samples). Biometrika 52(3/4), 591-611.
Simpson, G. G. 1936. Structure of a primitive Notoungulate cranium. American Museum Novitates 824, 1-31.

Stone, J. \& Telford, M. 2005. Fractal dimensions characterizing mammal teeth: a case study involving Elephantidae. Mammal Review 35, 123-28.

Strömberg, C. A. E. 2006. Evolution of hypsodonty in equids: Testing a hypothesis of adaptation. Paleobiology 32, 236-58.

Strömberg, C. A. E., Werdelin, L., Friis \& E. M., Saraç, G. 2007. The spread of grass-dominated habitats in Turkey and surrounding areas during the Cenozoic: Phytolith evidence. Palaeogeography, Palaeoclimatology, Palaeoecology 250, 18-49.

Strömberg, C. A. E., Dunn, R. E., Madden, R. H., Kohn, M. J. \& Carlini, A. A. 2013. Decoupling the spread of grasslands from the evolution of grazer-type herbivores in South America. Nature Communications 4, 1478.

Tauber, A. A. 1996. Los representantes del género Protypotherium (Mammalia, Notoungulata, Interatheridae) del Mioceno Temprano del sudoeste de la Provincia de Santa Cruz, República Argentina. Academia Nacional de Ciencias 95, 3-29.

Tauber, A. A. 1997. Bioestratigrafía de la formación Santa Cruz (Mioceno inferior) en el extremo sudeste de la Patagonia. Ameghiniana 34, 413-26.

Townsend, K. E. B. \& Croft, D. A. 2008. Diets of notoungulates from the Santa Cruz Formation, Argentina: New evidence from enamel microwear. Journal of Vertebrate Paleontology 28, 217 30.

Ungar, P. \& Williamson, M. 2000. Exploring the effects of tooth wear on functional morphology: a preliminary study using dental topographic analysis. Palaeontologia electronica 3, 1-18.

Van Valen, L. 1960. A functional index of hypsodonty. Evolution 14, $531-32$.

Vizcaíno, S. F., Bargo, M. S. \& Cassini, G. H. 2006. Dental occlusal surface area in relation to body mass, food habits and other biological features in fossil xenarthrans. Ameghiniana 43, 11-26.

Vizcaíno, S. F., Cassini, G. H., Fernicola, J. C. \& Bargo, M. S. 2011. Evaluating habitats and feeding habits through ecomorphological features in glyptodonts (Mammalia, Xenarthra). Ameghiniana 48 $305-19$

Vizcaíno, S. F., Kay, R. \& Bargo, M. S. 2012. Background for a paleoecological study of the Santa Cruz Formation (late Early Miocene) on the Atlantic Coast of Patagonia. In Vizcaíno, S. F., Kay, R. \& Bargo, M. S. (eds) Early Miocene Paleobiology in Patagonia: high-latitude paleocommunities of the Santa Cruz Formation, 1-22. Cambridge, UK \& New York: Cambridge University Press. $\mathrm{x}+370 \mathrm{pp}$.

Warton, D. I., Wright, I. J., Falster, D. S. \& Westoby, M. 2006. Bivariate line-fitting methods for allometry. Biological Reviews of the Cambridge Philosophical Society 81, 259-91.

Warton, D. I. \& Weber, N. C. 2002. Common slope tests for bivariate structural relationships. Biometrical Journal 44, 161-74.

Williams, S. H. \& Kay, R. F. 2001. A comparative test of adaptive explanations for hypsodonty in ungulates and rodents. Journal of Mammalian Evolution 8, 207-29.

Zar, J. H. 1999. Biostatistical Analysis. Upper Saddle River, New Jersey: Prentice Hall. 663 pp.

Zucol, A., Brea, M., Bellosi, E., Madden, R. \& Carlini, A. 2010. Phytolith studies in Gran Barranca (central Patagonia, Argentina): the middle-late Eocene. . In Madden, R. H., Carlini, A. A., Vucetich, M. G. \& Kay, R. F. (eds) The Paleontology of Gran Barranca: Evolution and Environmental Change through the Middle Cenozoic of Patagonia, 317-40. Cambridge, UK: Cambridge University Press. $458 \mathrm{pp}$. 
